\title{
Variations in soil seed banks of abandoned farmlands of various ages in Umukabia Umuagbom, Abia State, Nigeria
}

\author{
M. C. DIKE * and L. C. NWOSU \\ Department of Forestry and Environmental Management, Michael Okpara University of Agriculture, \\ Umudike, Nigeria. \\ *Corresponding author, E-mail: michael.dike@ymail.com
}

\begin{abstract}
A 3 x 5 Factorial Experiment in Randomized Complete Block design Experiment was used to study seeds stocked in soils of four abandoned farmlands and a secondary forest regrowth at Umukabia, Nigeria. Soil monoliths $25.0 \times 25.0 \times 10.0 \mathrm{~cm}$ were collected from the depths $0-10 \mathrm{~cm}$ and $10.0-20.0 \mathrm{~cm}$ from four abandoned farmlands and a secondary forest regrowth in the months of August, September and October, 2008. The experiment was replicated twice at each site for each month. Sieving- floatation method was adopted and two sieves of $1.85 \mathrm{~mm}$ and $0.80 \mathrm{~mm}$ mesh opening were used to sieve each soil monolith. The left over after sieving were air dried under the room temperature. The dried soil materials for each sample were viewed with a 10 magnifying hand lens to sort and enumerate the number of seeds contained in each sample. The seeds found at both depth of $0-10 \mathrm{~cm}$ and $10-20 \mathrm{~cm}$ were identified. After collection of the seeds, the data obtained were analyzed and the differences between the treatment means were separated using Fisher's - Least Significant differences $(\mathrm{F}-\mathrm{LSD})$ at $\mathrm{P}<0.05$. The total number of seeds counted from soil monoliths collected from the depths of $0.0-10.0 \mathrm{~cm}$ and 10.0-20.0 cm were 344 and 99 , respectively. For months, September with a mean of 12.90 seeds had the highest number of seeds while seven year old abandoned farmland with a mean of 14.67 seeds had the highest number of seeds amongst the various abandoned farmlands. Except seeds of Canariums chweinfurthii and Dialium guineense no other tree seeds were recorded. It was concluded that man should help in tree seeds dispersal and seedlings maintenance within abandoned farmland of the tropical rainforest to minimize the danger of most tree species being classified as being rare or endangered.
\end{abstract}

(c) 2013 International Formulae Group. All rights reserved.

Keywords: seed stocked, soil, sieving-floatation, secondary forest, regrowth.

\section{INTRODUCTION}

The tropical rainforest of Nigeria, which is made up of a complex mixture of woody plant species occurs at the southern part of Nigeria (Onochie, 1979; White, 1983). With the rapid population growth rate of over 1.2 percent per annum in Nigeria (Madu, 2001), most of the Nigerian rain forest areas have been put into various uses such as agriculture and urbanization. The increase in population has resulted in the increase in the number and sizes of farmlands. In some communities having severe land hunger, the same piece of land is cultivated annually. Weeding operations in most farmlands were done three times within 12 months resulting in the reduction in the total number of tree seedlings available for competition when the 
farmland is abandoned. According to Dike (2003) during weeding operations, farmers rarely give preference to seedlings of tree species listed as economic (Lancaster, 1961; Dike, 1992). Moreover, emergent and upper canopy tree species are not given special preference by farmers during either the clearing or burning operations. Some writers doubted whether the Nigerian rainforest could reproduce a forest as the one that existed then (Jones, 1956; Dike, 1992; 1993). Presently, many writers have reported that the rainforest is disappearing at an alarming rate of between 3.0 and 4.0 percent per annum (Okali, 1979; Okojie, 1998). Serious silvicultural experiments, such as the Group Method and the Tropical Shelterwood System aimed at understanding how the tropical rainforest regenerated itself naturally failed to achieve their major objectives (Lowe, 1975). Although plantations of indigenous tree species such as Khaya ivorensis and Milicia excelsa were tried, some insects such as Hypsiphyla robusta and Phytolymalata attacked and caused serious damages to the seedlings of Khaya ivorensis and Milicia excelsa, respectively. However, plantations of some exotic plant species such as Gmelina arborea and Tectona grandis were tried with success. It was recorded that the money involved in their establishment was much (Dike, 1992). Moreover, the release of Carbon (iv) oxide to the atmosphere caused a lot of environmental problems.

Nwoboshi (1982) recorded that tree species regenerated mainly from seeds. Seeds could come into abandoned farmlands through any of the following factors; explosive mechanism, wind, animal or water. Howe (1990) observed that birds and mammals were involved in plant seed dispersal. However, coppice from stumps and sprouts from roots contributed to colonize abandoned farmland (Dike, 2003). Two ecological groups of plant species, the pioneers and climax plant species were reported. The pioneers have seeds stored in the soil while most climax plant species have seedling banks. Seeds of both climax and pioneer plant species could come into the farmlands as seed rain when the farmer has abandoned the farmland. There is the need to evaluate the seeds in abandoned farmlands of various ages less than 8 years old. These seeds when they have germinated and established could presumably contribute significantly to form the secondary forest regrowth. According to Okali and Ola- Adams (1987), the composition of the forest could be determined early. If the desirable tree seedlings are lacking, the seedlings of the desirable tree species could be introduced by Enrichment planting. This paper reports seeds stored in abandoned farmlands of various ages less than 8 years. The study would be useful to foresters and environmentalists interested in climate change issues.

\section{MATERIALS AND METHODS}

The study was carried out at Umukabia Umuagbom in Okaiuga Alaike Community Abia State, Nigeria. Umukabia Umuagbom lies between latitudes $05^{\circ} 38^{\prime \prime}$ and $05^{\circ} 41^{\prime \prime} \mathrm{N}$ and longitudes $07^{\circ} 27^{\prime \prime}$ and $07^{0} 30^{\prime \prime} \mathrm{E}$. The climate is of the equatorial type. The temperature ranges between $19{ }^{\circ} \mathrm{C}$ and $34{ }^{\circ} \mathrm{C}$. There are two seasons; a wet and a dry season. The wet season starts from mid-March and ends in mid-November. The dry season continues until the mid-March of the following year. The annual rainfall ranges between 1500 and $3000 \mathrm{~mm}$. The relative humidity ranges between 60 and 98 percent during the wet season but could be as low as 40 percent during the peak of the dry Harmattan wind. The vegetation is tropical rainforest (White, 1983). The rainforest has been destroyed in most places. The abundant tree species are Anthonotha macrophylla, Dactyladenia barteri, Dialium guineense, Elaei sguineensis, Piptadeniastrum africanum 
and Pentaclethra macrophylla. Some abundant weeds include Aspilia africana, Chromolaena odorata, Panicum maximum and Ageratum conyzoides. Slash and burn agriculture is commonly practiced. There are no hills, mountains or plateau. The topography is gentle. The soil is well drained sandy loam. The soil parent material is the pre-Cambrian Basement Complex.

Four abandoned farmlands each greater than 30 hectares in size with ages 1, 2, 3, 7 and a secondary forest regrowth greater than 10 years were selected at random at Umukabia Umuagbom in Okaiuga Alaike Community. At each site, one hectare was selected at random and divided into $16,25.0 \times 25.0 \mathrm{~m}$ plots and numbered. On $14^{\text {th }}$ day of the months of August, September and October 2008, soil monoliths measuring $25.0 \times 25.0$ x $10.0 \mathrm{~cm}$ were collected from the central portion of one hectare study plot of each of the four abandoned farmlands and a secondary forest regrowth from the depths $0-10.0 \mathrm{~cm}$ and $10-20.0 \mathrm{~cm}$. The soil monolith collection was replicated twice at each site for each month. Consequently, four soil monoliths were collected from each site at each month. Each soil monolith was collected in a labeled and numbered polythene bag.

At each month, the collected soil monoliths were taken to the Ecological Centre of the University where each soil monolith was sieved using the sieving-flotation technique (Barralis et al., 1986). Two sieves were used. The upper sieve had $1.85 \mathrm{~mm}$ mesh opening and the lower sieve had 0.80 mm mesh opening. The materials remaining at the upper and lower sieves were collected for each sample at both sieves and were air dried under room temperature. Each of the air dried soil materials was viewed separately with ax10 magnifying hand lens to sort and enumerate the quantity of seeds stored in each of the samples. The length and width of each seed collected per monolith were measured using digital Mitutoyo, Japan caliper. The seeds were broadcast in labeled Petri dishes. The experiment is a 3x5 Factorial Experiment in a Randomized Complete Block Design (RCBD). Factor A is the months of collection while Factor B is the ages of the farmlands. The data obtained were statistically analyzed and the differences between treatment means were separated using Fisher's-Least Significant Differences (F-LSD) at $\mathrm{P}<0.05$, according to the procedures of Steel and Torrie (1980).

\section{RESULTS AND DISCUSSION}

Plant seeds were found in all the soil monoliths collected at the depth of $0-10.0 \mathrm{~cm}$ in the three months of study. There was no significant effect of time (months) of collection, various ages of the abandoned farmlands and the interaction (TXA) of both time (months) and ages (years) on the number of seeds obtained from the soil monoliths collected at the depth of $0-10 \mathrm{~cm}$ at the study area, Umukabia in Umuahia, Nigeria (Table 1). A total of 344 seeds were enumerated from the soil monoliths taken from $0-10 \mathrm{~cm}$ depth. Ninety-six percent of the total numbers of seeds from soil monoliths were those of grasses while four percent were those of two trees; Canariums chweinfurthii and Dialium guineense and a climber Merremia aegytica. The result agreed with the records of Dike and Ezeigbo (2011), who observed seeds of mainly grasses in soil monoliths taken from a swampy area and Hevea brasiliensis plantation at Umudike, Nigeria.

The result agreed also with the record of Dike (2003), who observed that economic trees species and their seedlings within farmlands were not given preference by farmers. Consequently, the source of tree seeds for colonization after the farmland has been abandoned becomes difficult. Dike and Aguguom (2010), working at Umudike, Nigeria recorded that most Nigerian rainforest tree fruits and seeds could not be dispersed for over $100 \mathrm{~m}$ from the center of the dispersing 
tree species presumably because of low wind speed of between 0.5 and $3.5 \mathrm{~ms}^{-1}$ at a height of $2.0 \mathrm{~m}$ above the ground and the relatively heavy seeds produced by the tree species. Tree seeds were poorly represented in the soil monoliths taken from the abandoned farmlands. Explosive dispersing tree species such as Pentaclethra macrophylla, Albizia zygia and Brachystegia nigerica were not observed within $100.00 \mathrm{~m}$ from the studied plots. Moreover, wild animals useful in tree seed dispersal were few. Grasses were very abundant presumably because grasses produced numerous viable seeds annually. The observed seeds measured between 0.77 and $3.64 \mathrm{~mm}$ in length and between 0.40 and $2.69 \mathrm{~mm}$ in width. These relatively small seeds of grasses are easily carried by water, earthworms and wind. A total of 99 seeds were enumerated in soil monoliths from the depth $10-20.0 \mathrm{~cm}$. The time (months) of soil seed collection and the interaction (TxA) of time months and ages (years) had no significant effect on the number of seeds found in the soil monoliths collected at the depth of $10-20.0 \mathrm{~cm}$. Age (years) of the abandoned farmlands significantly influenced the number of seeds found in soil monoliths of $10-20.0 \mathrm{~cm}$ depth. The greater than 10 years abandoned farmlands had significantly higher number of seeds than three year old farmlands. The number of seeds obtained from the seven years old abandoned farmland was similar to those of one year and two years old farmlands. No significant differences existed between the number of seeds found in the one - year old and two years old farmlands (Table 2). These seeds were those of grasses only.

Table 1: The mean number of seeds found from $25 \times 25 \times 10 \mathrm{~cm}$ soil monoliths taken from abandoned farmlands at Umukabia Umuagbom, Nigeria from 0-10.0 cm soil depth.

\begin{tabular}{lcccccc}
\hline \multicolumn{7}{c}{ Ages (years) of the abandoned farmlands } \\
\hline Time (months) & $1-$ & $2-$ & $3-$ & $7-$ & $>10$ & Mean \\
August, 2008 & 16.50 & 11.00 & 11.50 & 10.00 & 13.00 & 12.40 \\
September 2008 & 10.50 & 19.00 & 9.00 & 14.00 & 12.00 & 12.90 \\
October 2008 & 4.50 & 5.00 & 8.00 & 20.00 & 800 & 9.10 \\
Mean & 10.50 & 11.67 & 9.50 & 14.67 & 11.00 & \\
\hline \multicolumn{7}{c}{ F- LSD (0.05); Time (Months) = NS; Age (years) = NS; Interaction (TxA) = NS }
\end{tabular}

Table 2: Mean number of seeds in each site, for each month with $10-20 \mathrm{~cm}$ soil depth.

\begin{tabular}{lcccccc}
\hline \multicolumn{7}{c}{ Ages (years) of the abandoned farmlands } \\
\hline Time (months) & $1-$ & $2-$ & $3-$ & $7-$ & $>7$ & Mean \\
August, 2008 & 5.00 & 1.00 & 1.00 & 3.00 & 3.00 & 2.60 \\
September 2008 & 2.50 & 7.00 & 2.00 & 6.50 & 1.00 & 3.80 \\
October 2008 & 2.50 & 2.50 & 2.50 & 8.00 & 2.00 & 3.50 \\
Mean & 3.33 & 3.50 & 1.83 & 5.83 & 2.00 & \\
\hline F - LSD (0.05); Time (Months) $=$ NS; Age (Years) $=2.66^{*}$; Interaction (TxA) = NS; * Significant; NS : not significant
\end{tabular}


Seeds of the emergent, upper and lower canopy tree species were poorly recorded in soil monoliths collected from abandoned farmlands of various ages in Umukabia Umuagbom, Nigeria. Farmers rarely leave the seedlings of tree species listed as economic during the weeding operation. Many plant ecologists have recorded the inability and difficulty of fruits/seeds of most Nigerian rainforest tree species to be dispersed for up to $200 \mathrm{~m}$ due to the relatively heavy weight and poor wind speed (Dike, 2004; Dike and Aguguom, 2010). Most emergent and upper canopy tree fruits/seeds such as those of Entandrophragma spp, Khaya spp, and Gossweilerodendron balsamiferum are therefore poorly represented in soil monoliths collected from abandoned farmlands $200 \mathrm{~m}$ away from the tree dispersing its fruits/seeds. The poor ability of tree species to disperse their fruits/seeds was observed also by Swaine and Hall, (1980) working at Range Forest Reserve, Ghana. They found many seedlings of Terminalia ivorensis which the dispersing tree was $50.0 \mathrm{~m}$ away from their study plot.

Abandoned farmlands of Nigerian rainforest where standard tree species were not left during clear felling operation had been classified as land capable of bearing forest but in various degrees of degradations (Okali, 1979). Some monkeys (Cercopithecus spp) and large birds are mostly pulp eaters and could disperse plant seeds such as those of Milicia excelsa, Chrysophyllum albidum, Landolphia owariensis and Spondias mombin close to the plant species producing the fruits. A similar observation has been recorded by Gautier - Hion (1990). Many animals such as Loxodonta africana cyclotis (elephants), Syncerus cafer (buffaloes) and Cercopithecus spp (monkeys) are presently very scarce in abandoned farmland because of the serious threat on their lives by poachers. Seed dispersal by animals is therefore no longer very effective in abandoned farmlands within Umukabia Umuagbom, Nigeria.

\section{Conclusion}

It is concluded that some standard trees should be left during the clearing operations to enable fruits/seeds to be dispersed from these standard trees. It appears that if the rainforest is not assisted, grasses, climbers and shrubs could be abundant within the rainforest. The functions of the tree species would be lacking, leading to serious climatic problems.

\section{REFERENCES}

Barralis A, Chadoeuf R, Gouet JP. 1986. Spatial pattern analyses of weed seeds in the cultivated soil seed Bank. J. App. Eco., 28: 721 - 730.

Dike MC. 1992. Tree regeneration, recruitment and mortality in Nigeria Tropical Moist Forests. Ph.D thesis, University of Ibadan, Nigeria, p. 235.

Dike MC. 2003. Early plant succession on mechanically cleared moist forestland in south-eastern Nigerian rainforest. J. Trop. Forest Res., 19(2): $104-116$.

Dike MC. 2004. Relationship between fruits and seeds sizes, germination and early seedling growth of some edible plant species in southeastern Nigerian rainforests. Glo. J. Pure App. Sci., 15 (2): $141-150$.

Dike MC, Ezeigbo. 2011. Comparative study of soil seed stock in swampy area and Heveabrasiliensis plantation at Umudike Nigeria. ARPN J. Agric. Bio. Sci., 6(9): $1-8$.

Gautier-Hion A. 1990. Interactions among fruit and Vertebrate fruit eaters in an African tropical rainforest. In Reproductive Ecology for Tropical Forest Plants, Bawa KS, Hadley M (eds). UNESCO and the Parthenon Publishing Group Limited, Casterton Hall: Carnforth; $219-230$.

Howe HF. 1990. Seed dispersed by birds and mammals: Implications for seedling demography. In Reproductive Ecology for Tropical Forest Plants, Bawa KS, Hadley 
M (eds.). Man and the Biosphere Series vol. 7. UNESCO and the Parthenon Publishing Group Limited, Casterton Hall: Carnforth; $191-218$.

Jones EW. 1956. Ecological studies in the rainforest of Southern Nigeria. IV. The plateau forest of Okomu forest reserve. $J$. Eco. 44: 83 - 117.

Lancaster PC. 1961. Experiment with natural regeneration in the Omo forest reserve. A report on trial of methods of obtaining natural regeneration in lowland rainforest in southern Nigeria. (Investigation No. 208) Nigerian Forestry Information Bulletin (New series No. 13). Federal Printer, Lagos.

Lowe RG. 1975. Nigerian experience with natural regeneration in tropical moist forest. Background papers, Technical conference on the Tropical Moist Forest. FAO, Rome.

Madu IA. 2001. Population and Environmental Problems. In Geographical Perspectives Problems and Management in Nigeria. Ofomata GEK, Phil-Eze PO (eds). Jamoe Enterprises: Nigeria; 80 - 95

Nwoboshi LC. 1982. Tropical Silviculture. Principles and Techniques. Ibadan University Press: Ibadan, Nigeria; 333.
Oguntala AB, Soladoye MO, Ugbogu OA. 2000. Endangered tree species of the Nigerian flora. Nigerian Journal of Forestry, 30: $15-21$.

Okali DUU. 1979. Preface. In The Nigerian Rainforest Ecosystem, Okali DUU (ed). University of Ibadan Press: Ibadan; 5-8.

Okali DUU, Ola-Adams BA. 1987. Tree Population changer in treated rainforest at Omo forest Reserve, South - Western Nigeria. J. Trop. Eco., 3: 291-313.

Onochie CFA. 1979. The Rainforest Ecosystem: an Overview in the Nigerian Rainforest Ecosystem, Okali DUU (ed). University of Ibadan Press: Ibadan; 1-13.

Steel RG, Torrie JH. 1980. Principles of Statistic. A Biometrical Approach $\left(2^{\text {nd }}\right.$ edn). MC Graw Hill Book Co. Inc.: New York.

Swaine MD, Hall JB. 1983. Early Succession on cleared forest land in Ghana. J. Eco., 71: $601-627$.

Swaine MD, Whitmore TC. 1988. On the definition of ecological species groups in the tropical rainforest. Vegetatio, 73: 8081.

White. 1983. The Vegetation of Africa. UNESCO: Paris. 